\title{
SPECIAL FEATURE: PREFACE \\ Recent Monetary Policy 2 \\ Preface to the special feature on recent monetary policy 2
}

\author{
Naotsugu Hayashi ${ }^{1}$
}

Published online: 21 November 2020

(c) Japan Economic Policy Association (JEPA) 2020

Keywords Global financial crisis · Non-traditional monetary policy $\cdot$ Quantitative monetary easing $\cdot$ Zero interest rate policy $\cdot$ Negative interest rate policy

Triggered by the Lehman shock in September 2008, not only developed countries but also developing countries began to suffer from the Global Financial Crisis (GFC), and fell into a prolonged deflationary recession. Most of the governments issued large-scale deficit government bonds to expand their fiscal expenditures. The central banks adopted not only ultra-low interest rate policy, zero interest rate policy (ZIR), and negative interest rate policy (NIR), but also quantitative monetary easing (QE) that significantly increased the monetary base, yield curve control, forward guidance, etc. These new policies are called non-traditional (or non-conventional) monetary policies. But they have not been achieving the desired effects.

Then, the International Conferences of the Japan Economic Policy Association (JEPA), determined to hold the plenary session on "Active Monetary Easing and Stable Growth Policy" in 2018, and the special lectures on "Financial Economy after 2020: Non-Traditional Monetary Policies and their Effects" in 2019.

The purposes of the former conference in 2018 were to investigate and analyze the causes of the serious deflation and the effects of these new non-traditional policies on the economy and to clarify the effective policies to overcome deflation and recover stable growth especially from the macroeconomic viewpoint, with comparing them internationally. The research papers and comment papers were published in the International Journal of Economic Policy Studies, Vol. 13, Issue 2, 2019, Springer, as was summarized by Hayashi [2].

The purposes of the latter conference in 2019 were almost the same as those in 2018 , but the difference is that they were from the viewpoints of not only the macroeconomy but also individual financial industries. The research papers and comment papers are now being published in the International Journal of Economic Policy Studies, Vol. 14, Issue 2, 2020, Springer, as was summarized by Hayashi.

The research achievements published in the Special features on recent monetary policy analyzed the non-traditional monetary policies and their effects and impacts

Naotsugu Hayashi

n.hayashi@hosei.ac.jp

1 Faculty of Business Administration, Hosei University, Tokyo, Japan 
on the real economy and industries from various analytical perspectives, such as practitioners, empirical analysts, and theorists, who participated in these series of international conferences. They will provide useful and valuable implications for all politicians, scholars and the public who wish for achieving $2 \%$ inflation target, breaking out of serious deflation and a recovery in stable growth.

Professor Jerry L Jordan, Pacific Academy for Advanced Studies and a former President of the Federal Reserve Bank of Cleveland, published Jordan [5], based on his keynote lecture in 2018, titled "Issues and Challenges of Monetary and Fiscal Policies Caused by Quantity Easing by Central Banks", from the viewpoint of Neo-liberalism and New Monetarism. Professor Naotsugu Hayashi, Hosei University, submitted Hayashi [3], based on his comments and questions on the lecture especially in the case of Japanese monetary and economic policies.

Professor Sayuri Shirai, Keio University, published Shirai [9], based on her keynote lecture, titled "Overview of Bank of Japan's Monetary Easing Policy" especially from the practical viewpoint of a former member of the Policy Board of the Bank of Japan. Professor Megumu Kigugawa, International University of Kagoshima, submitted Kinugawa [6], based on his comments and questions on the lecture, from the viewpoint of monetary theory.

Professor Emeritus Shimizu, Hitotsubashi university and a former President of the Japan Association of Monetary Economics, published Simizu [8], based on his keynote lecture, titled "Are Non-Traditional Monetary Policies Effective for Stable Growth?". Professor Keiichiro Kobayashi, Keio University, submitted Kobayashi [7], based on his comments and questions on the lecture, especially from practical viewpoints.

All of these presenters and discussants revised their papers based on the discussions and comments, and referees of the IJEPS refereed these papers. This special issue is the product of a compilation of these studies and arguments.

After the Special Lectures in 2019, Professor Yutaka Harada, a former member of the Policy Board of the Bank of Japan, published Harada [1], based on his keynote lecture titled "Non-traditional Monetary Policies and their Effects on the Economy" from the view point of a central banker. Harada [1] explains the means of non-traditional monetary policies in chronological order and positively demonstrates the impacts on employment, productivity, fiscal balance, banking industry profits, and lending/deposit ratios in the real economy. But it also admits that it failed to achieve its $2 \%$ inflation target.

Professor Emeritus Naotsugu Hayashi, of Hosei University, a former Vice President of the Japan Economic Policy Association, submitted Hayashi [4], based on his comments and questions on the lecture from a theoretical viewpoint. Hayashi [4] analyzes important key issues of non-traditional monetary policies raised by Harada [1], and tries to clarify the reasons why the BOJ could not achieve the $2 \%$ inflation target and proposes desirable new policy measures to achieve the inflation target, to raise real growth rate stably and to restore monetary normalization.

Dr. Willem Thorbecke, of Research Institute of Economy, Trade and Industry, published Thorbecke [10], based on his keynote lecture titled " Non-traditional Monetary Policies and the Future of the Financial Industries", especially from the viewpoint of empirical analysis of financial industries. Thorbecke [10] investigates 
how expansionary monetary policy after the Global Financial Crisis (GFC) has affected the U.S. banking sector. This proposes that the Fed should take account of the impact of their policies on the banking sector, since an interruption on the flow of credit through the financial system could prevent funds from going to the most promising firms. It points out that this misallocation of resources could then hinder long-term economic growth.

These presenters and discussants revised their papers based on the discussions and comments, and anonymous referees of the IJEPS reviewed and refereed these papers. This special issue is the product of a compilation of these studies and arguments.

Naotsugu Hayashi

Guest-Editor of the IJEPS

Vice Chair of the International Committee of the JEPA in 2019

Professor Emeritus, Hosei University

\section{References}

1. Harada, Y. (2020). Non-traditional monetary policies and their effects on the economy. International Journal of Economic Policy Studies. https://doi.org/10.1007/s42495-020-00045-y

2. Hayashi, N. (2019). Preface to the special feature on recent monetary policy. International Journal of Economic Policy Studies, 13(2), 273-274.

3. Hayashi, N. (2019). Recent unorthodox monetary policies vs. orthodox theory of monetary policy: comments and views on Jordan. International Journal of Economic Policy Studies, 13(2), 285-317.

4. Hayashi, N. (2020). BOJ's non-traditional monetary policies and their effects on the Japanese economy: comments and views on Harada. International Journal of Economic Policy Studies. https://doi. org/10.1007/s42495-020-00047-w

5. Jordan, J. L. (2019). New challenges for monetary and fiscal policies. International Journal of Economic Policy Studies, 13(2), 275-284.

6. Kinugawa, M. (2019). The unconventional monetary policy of the Bank of Japan during the period 2013-2018: comments and views on Shirai. International Journal of Economic Policy Studies. https ://doi.org/10.1007/s42495-019-00018-w

7. Kobayashi, K. (2019). Why deflation continues under extraordinary monetary expansion? Comments and views on Shimizu. International Journal of Economic Policy Studies, 13(2), 383-388.

8. Shimizu, Y. (2019). Monetary easing policy and stable growth: a theoretic approach. International Journal of Economic Policy Studies, 13(2), 359-382.

9. Shirai, S. (2019). Overview of the Bank of Japan's unconventional monetary policy during the period 2013-2018. International Journal of Economic Policy Studies, 13(2), 319-345.

10. Thorbecke, W. (2020). Non-traditional monetary policy and the future of the financial industries. International Journal of Economic Policy Studies. https://doi.org/10.1007/s42495-020-00044-z

Publisher's Note Springer Nature remains neutral with regard to jurisdictional claims in published maps and institutional affiliations. 